\title{
BEBAN KERJA PERAWAT TERHADAP IMPLEMENTASI PATIENT SAFETY DI RUANG RAWAT INAP
}

\author{
Dwi Retnaningsih, Diah Fatmawati \\ Program Studi S1 Keperawatan STIKES Widya Husada Semarang \\ email: dwiretnaningsih81@yahoo.co.id
}

\begin{abstract}
One of the goals of patient safety systems is a declining unexpected events which are results of multiple problems included humane resources, inadequate policies and procedures to decline in events that could occur due to several problems and one of them is the problem of human resources, policies and procedures even technical failures of factors that risk for causing infection. One of them is high nurse's workload due to insufficient staffs or nurses. The purpose of this study was to examine the relationship between the nurse's workload and the implementation of patient safety in the inpatient units at Tugurejo Public Hospital Semarang. A cross sectional study invited 155 nurses to participate. The total sampling technique was applied. Chi Square test tested the hypothesis. The result showed that the nurse's workload tended to high level $(58.7 \%)$, while mostly the implementation of patient safety was unfavorable $(60.6 \%)$. Chi Square test reported $X^{2}=6.807(p=0.0009)$. There is a significant relationship between the nurse's workload and the implementation of patient safety in the hospital inpatient Tugurejo Semarang.
\end{abstract}

Keywords: The workload of nurses, implementation of patient safety.

\section{ABSTRAK}

Salah satu tujuan dari sistem keselamatan pasien yaitu turunnya kejadian tidak diharapkan yang bisa terjadi karena beberapa masalah dan salah satunya yakni masalah sumber daya manusia, kebijakan dan prosedur yang tidak adekuat dan kegagalan faktor teknis yang berpengaruh pada risiko terjadinya infeksi dirumah sakit. Salah satunya yaitu tingginya beban kerja perawat akitab terbatasnya staf atau perawat. Tujuan dari penelitian ini adalah menguji hubungan antara beban kerja perawat dan implementasi patient safety di ruang rawat inap RSUD Tugurejo semarang. Penelitian cross-sectional dengan mengundang 155 perawat untuk terlibat. Teknik total sampling diaplikasikan. Uji Chi Square dilakukan untuk uji hipotesis. Hasil penelitian menunjukan bahwa beban kerja perawat di ruang rawat inap tinggi $(58,7 \%)$, sedangkan kebanyakan implementasi patient safety kurang baik $(60,6 \%)$. Hasil analisis Chi Square memperoleh $X^{2}=6.807(p=0.0009)$. Dapat disimpulkan ada hubungan bermakna antara beban kerja perawat dengan implementasi patient safety di ruang rawat inap RSUD Tugurejo Semarang.

Kata kunci: Beban kerja perawat, Implementasi patient safety.

\section{PENDAHULUAN}

Memberikan mutu pelayanan kesehatan yang optimal, rumah sakit memerlukan tenaga-tenaga kesehatan yang produktif dalam bekerja. Tenaga-tenaga kesehatan tesebut yakni dokter, perawat, bidan, apoteker, fisioterapi dan tenaga kesehatan lainnya (Fatimah, 2012). 
Namun ada aspek yang juga berpengaruh terhadap mutu pelayanan di sebuah rumah sakit. Dan seharusnya menjadi perhatian besar bagi pihak rumah sakit sebagai penyedia pelayanan. Aspek tersebut adalah keselamatan pasien (patient safety). Pasien bukan hanya membutuhkan pelayanan yang berkualitas tetapi juga suatu kondisi yang meyakinkan mereka bahwa pelayanan yang diberikan adalah pelayanan yang aman dan tidak membahayakan diri mereka (Permenkes, 2011).

Salah satu tujuan penting dari penerapan sistem keselamatan pasien di rumah sakit adalah mencegah dan mengurangi Insiden Keselamatan Pasien (IKP) adalah suatu kejadian atau situasi yang dapat mengakibatkan atau berpotensi mengakibatkan cidera pada pasien. IKP meliputi kejadian yang tidak diharapkan (KTD), kejadian nyaris cidera (KNC), kejadian potensial cidera (KPC) dan kejadian cidera dalam proses asuhan pelayanan medis maupun asuhan pelayanan keperawatan dari yang ringan sampai yang berat menurut Komite Keselamatan Pasien Rumah Sakit (KKP$R S, 2007)$. Dihubungkan dengan teoriteori yang menjelaskan terjadinya IKP cukup banyak aspek yang harus diperhatikan dalam implementasi sistem keselamatan pasien di Indonesia. Implementasi pasien di rumah sakit adalah mendesain pekerjaan dengan memperhatikan faktor manusia. Ini berarti dalam penataannya, memperhitungkan jam kerja, beban kerja, staffing rasio dan sift dengan memperhatikan faktor kelelahan, siklus tidur dan lain-lain (Hamdani, 2007).

Rumah sakit sebagai organisasi sistem pelayanan kesehatan mempunyai elemen-elemen yang saling interaksi dan interdependesi yang kuat. Elemen SDM dalam organisasi pelayanan kesehatan mempunyai peran sentral dalam orientasi pencapaian tujuan organisasi, manajemen SDM sangatlah penting, sebab organisasi/perusahaan yang mengimplementasikannya secara sungguh-sungguh, ternyata telah berhasil mewujudkan eksistensinya secara kompetitif dan mencapai sukses seperti yang di inginkan (Nawawi,2008)

Perawat sebagai salah satu komponen sumber daya manusia (SDM) dalam sistem pelayanan kesehatan dirumah sakit, yang bertugas langsung pada garis depan dan mempunyai waktu lebih banyak berhadapan dengan pasien, tanpa mengabaikan peran tenaga kerja lainnya. Mutu pelayanan rumah sakit sebagian ditentukan juga oleh peran perawat. Dimensi mutu pelayanan rumah sakit yang luas dapat berubah sebagai dinamisasi dan adaptasi perkembangan waktu dan tuntutan pasien. Akhir-akhir ini mutu pelayanan yang berorientasi kepada keselamatan pasien menjadi lebih menonjol (prahasto, 2008).

Kinerja perawat dipengaruhi oleh 3 variabel yaitu variabel individu, variabel organisasi dan variabel psikologis. Variabel individu, terdiri dari kemampuan, keterampilan, pengetahuan, demografi dan latar belakang keluarga, variabel psikologis terdiri dari persepsi, sikap, motivasi, kepribadian dan belajar. Sedangkan variabel organisasi terdiri dari sumber daya, imbalan, beban kerja, struktur, supervisi dan kepemimpinan (Firmansyah 2009). Salah satu tujuan dari sistem keselamatan pasien (patient safety) yaitu menurunnya KTD di rumah sakit. (Gibson, 1987) Menurut (Agency For Healtcare Research And Quality) AHRQ, (2003) dalam Mulyati (2011), menyatakan bahwa KTD bisa terjadi dikarenakan oleh beberapa masalah, 
Masalah tersebut yakni masalah sumber daya manusia,kebijakan dan prosedur yang tidak adekuat dan kegagalankegagalan teknis faktor yang berpengaruh dalam resiko terjadinya infeksi dirumah sakit salah satunya yaitu beban kerja yang tidak sesuai dengan staf/ perawat yang tersedia, (Griffiths et all,2008).

WHO pada tahun 2004 mengumpulkan angka penelitian rumah sakit di berbagai negara yaitu Amerika, Inggris, Denmark, Dan Australia. Di temukan (kejadian tak diharapkan) KTD dengan rentang 3,2 - 16,6. Data-data tersebut menjadikan pemicu berbagai negara untuk segera melakukan penelitian dan pengembangan sistem keselamatan pasien.(DepKes.2006).

Laporan insiden baru tercatat di Komite Keselamatan Pasien Rumah Sakit (KKPRS) mulai September 2006. Hasil laporan insiden sejak September 2006 sampai Agustus 2007 sebanyak 145 insiden. Sedangkan untuk kasus infeksi nosokomial, angka kejadiannya cukup tinggi di negara-negara maju. Di Amerika Serikat terjadi 20 ribu kematian setiap tahun akibat infeksi nosokomial. Di seluruh dunia 10\% pasien rawat inap di rumah sakit mengalami infeksi yang baru selama dirawat atau sebesar 1,4 juta infeksi setiap tahun. Di Indonesia sendiri, laporan insiden keselamatan pasien berdasarkan provinsi pada tahun 2007 di temukan di provinsi DKI Jakarta menempati urutan tertinggi yaitu $37.9 \%$ diantarannya delapan provinsi lainya (Jawa tengah $15.9 \%$, di DI Yogyakarta $13.8 \%$, Jawa timur $11.7 \%$, Sumatra selatan $6.9 \%$, Jawa barat $2.8 \%$, bali $1.8 \%$, Aceh $10.7 \%$, dan sulawesi selatan $0.7 \%$ ). (KKP-RS, 2008)

Keselamatan (safety) telah menjadi isu global untuk rumah sakit. Ada lima isu penting yang terkait dengan keselamatan di rumah sakit yaitu keselamatan pasien (patient safety), keselamatan pekerja atau petugas kesehatan, keselamatan bangunan dan peralatan di rumah sakit yang bisa berdampak terhadap keselamatan pasien dan petugas, keselamatan lingkungan yang berdampak terhadap pencemaran lingkungan dan keselamatan bisnis rumah sakit yang terkait dengan kelangsungan hidup rumah sakit, menurut Departemen Kesehatan Republik Indonesia (Depkes RI, 2006).

Pada tahun 2013 telah dilakukan penelitian oleh Iswatun mahasiswa program pasca sarjana Universitas Sebelas Maret Surakarta dengan judul penelitian "Hubungan Beban Kerja Dan Motivasi Kerja Dengan Kinerja Perawat Di RSUD Dr. Soegiri Lamongan". Di dapatkan faktor-faktor yang mempengaruhi kinerja perawat adalah beban kerja, motivasi, gaji, variasi kerja, pengawas/supervisor, promosi dan kondisi kerja.

Pengambilan data awal dilakukan di RSUD tugurejo semarang, kepada lima orang perawat di dapatkan bahwa salah satu pemicu dari kejadian tidak diharapkan yang terjadi, adalah akibat dari beban kerja perawat yang tinggi yang menyebabkan tingkat komunikasi antar perawat berkurang. Dan menurut wawancara pada salah satu perawat di dapatkan informasi bahwa beban kerja perawat di RSUD Tugurejo cukup tinggi, dikarenakan jumlah tenaga perawat yang kurang memadai atau mencukupi untuk jumlah pasien, serta tugas perawat yang berlebih yaitu dengan mengerjakan tugas yang bukan semestinya seperti mengoplos obat yang seharusnya dilakukan oleh bidang farmasi, menulis diit makanan yang sesuai oleh pasien 
yang seharusnya dilakukan oleh bagian ahli gizi dan lain sebagainya. Banyaknya tugas tambahan yang harus dikerjakan oleh perawat dapat menganggu penampilan kerja dari perawat. Akibat negatif dari banyaknya tugas tambahan perawat diantaranya timbulnya emosi perawat yang tidak sesuai dengan yang diharapkan dan berdampak buruk bagi produktifitas perawat (Irwady, 2007). Beban kerja yang terlalu tinggi akan menyebabkan seorang perawat stess, dampak buruk yang dapat ditimbulkan jika seorang perawat mengalami stres ialah dapat mengganggu interaksi sosialnya, baik itu dengan rekan kerja, dokter maupun pasien. Efektivitas kerja dapat pula menjadi terganggu, karena pada umumnya apabila seseorang mengalami stres, maka akan terjadi gangguan baik itu pada psikologisnya maupun keadaan fisiologisnya(Anil JC, 2010).

Berdasarkan uraian tersebut peneliti tertarik untuk meneliti "Bagaimana Hubungan beban kerja perawat terhadap implementasi patient safety di RSUD Tugurejo Semarang?"

\section{METODE PENELITIAN}

Penelitian ini merupakan penelitian deskriptif kuantitatif. Penelitian deskriptif merupakan penelitian yang dimaksudkan untuk mengangkat fakta, keadaan, variabel, dan fenomena yang terjadi selama penelitian berlangsung dan menyajikan apa adanya. (Wasis, 2008). Penelitian ini menggunakan desain studi korelasi yaitu hubungan antara dua variabel atau lebih. Penelitian ini menganalisis hubungan antara variabel bebas dengan variabel terikat.

Desain penelitian ini menggunakan pendekatan belah lintang (cross sectional), dimana variabel sebab dan variabel akibat (variabel dependent dan independent) di ukur dalam waktu yang bersamaan dan sesaat atau data diperoleh saat ini juga. (Nursalam, 2008). Lokasi atau tempat pada penelitian Hubungan Beban Kerja Perawat Terhadap Implementasi Patient Safety, dilakukan di ruang rawat inap RSUD Tugurejo Semarang, diantaranya ruang Amarilis, Alamanda, Anggrek, Bougenvile, Dahlia, Flamboyan, Kenanga, Mawar, ICU, HCU, ICCU, dan Tulip.

Untuk variabel implementasi pasien safety menggunakan koesioner dengan 9 pertanyaan tentang Sembilan Solusi "Life-Saving" Keselamatan Pasien Rumah Sakit, atau 9 Solusi. Dengan pertanyaan favorable dan pertanyaan unfavorable. Cara pengumpulan data dengan Data primer dalam penelitian ini untuk variabel beban kerja perawat didapatkan dari hasil observasi atau pengamatan. Dan untuk variabel implementasi pasient safety didapat oleh peneliti dari hasil kuesioner yang dibagikan kepada para perawat RSUD Tugurejo Semarang. Serta Data skunder dalam penelitian ini didapat oleh peneliti dari data yang telah dikumpulkan oleh pihak RSUD Tugurejo seperti data dari bagian keperawatan dan rekam medis.

Analisis data dilakukan dengan menggunakan Analisa Univariat dan Bivariat, dimana analisis univariat dilakukan pada variabel beban kerja perawat dan implementasi patient safety pada ruang rawat inap di RSUD tugurejo semarang,

\section{HASIL DAN PEMBAHASAN}

\section{Jenis kelamin}

Hasil penelitian menemukan bahwa sebagian besar berjenis kelamin perempuan yaitu 84 orang $(54,2 \%)$. Kenyataan ini menunjukan bahwa 
pekerjaan sebagai perawat masih banyak diminati oleh kaum perempuan. Peminatan pada pekerjaan sebagai perawat ini juga lebih banyak diminati oleh seorang wanita. Yang identik dengan kesabaran dan tingkat ketelitian yang tinggi dari pada laki-laki sehingga sangat cocok untuk memberikan asuhan keperawatan terhadap pasien dengan segala macam karakteristik dan keinginan yang bermacam-macam. Menurut Izzudin (2006) menyebutkan bahwa perawat perempuan mempunyai kemampuan dalam penyusunan asuhan keperawatan sembilan kali lebih baik daripada perawat laki-laki. Perawat perempuan pada umumnya mempunyai kelebihan kesabaran, ketelitian tanggap, kelembutan, naluri mendidik, merawat, mengasuh, melayani, membimbing, dan sesuai dengan pekerjaan sebagai perawat dengan memberikan asuhan keperawatan yang terbaik kepada pasien.

Umur

Hasil penelitian menemukan bahwa sebagian sebagian besar kelompok umur responden adalah 20-30 yaitu sebanyak 78 orang $(50,3 \%)$. Pada kelompok umur ini responden tergolong usia muda, dengan pertimbangan bahwa perawat yang berumur muda memiliki motivasi dan produktivitas yang tinggi dibandingkan dengan umur yang lanjut tenaga muda secara umum memiliki kondisi kesehatan dan ketrampilan fisik yang lebih baik dibandingkan dengan yang berusia lanjut, sehingga dapat menunjang kerja di tempat kerja (suma'mur, 1995).

\section{Status perkawinan}

Hasil penelitian menunjukan bahwa sebagian responden lebih besar telah berstatus menikah yaitu sebanyak 88 perawat $(56,8 \%)$. Perawat yang berstatus menikah terutama yang berjenis kelamin perempuan memiliki peran ganda yaitu didalam pekerjaanya dan dirumah sebagai ibu rumah tangga. Sedangkan yang berjenis kelamin laki-laki dituntut lebih keras sehingga kecenderungan terjadinya beban dan stres semakin besar. Dan stres yang dialami oleh pekerja yang berstatus kawin disebabkan oleh work family conflict yang dapat menjadi suatu suatu sumber stres individu, baik beban kerja yang berlebih (wijono, 2006).

\section{Pendidikan terakhir}

Dari hasil penelitian menunjukan bahwa sebagian besar responden pada tingkat pendidikan $S 1$ yaitu sebanyak 63 responden $(40,6)$. Tingkat pendidikan seseorang berpengaruh dalam memberikan respon terhadap sesuatu yang datang dari luar. Termasuk peningkatan jumlah pasien pada waktu tertentu. Orang berpendidikan tinggi akan lebih rasional dan kreatif serta terbuka dalam menerima adanya bermacam usaha pembaharuan, ia juga akan lebih dapat menyesuaikan diri terhadap berbagai perubahan. (Hani,1989).

\section{Lama bekerja}

Hasil penelitian menunjuka bahwa responden terbanyak bekerja pada rentang waktu 1-3 tahun sebanyak 54 responden $(34,8 \%)$. Masa kerja tersebut masih tergolong baru dan pengalaman kerja juga ikut menentukan kinerja seseorang. Semakin lama masa kerja maka kecakapan akan lebih baik karena sudah menyesuaikan diri dengan pekerjaanya .Seseorang akan mencapai kepuasan tertentu bila sudah mampu menyesuaikan diri dengan lingkunganya (Handoko, 1989). 
Tabel 1 Kondisi Beban Kerja dan

Patient Safety N= 155

\begin{tabular}{ll}
\hline Variabel & $\mathbf{n ~ ( \% )}$ \\
\hline Beban Kerja & \\
Ringan & $64(41,3)$ \\
Berat /Tinggi & $91(58,7)$ \\
Patient Safety & \\
Baik & $61(39,4)$ \\
Kurang & $94(60,6)$ \\
\hline
\end{tabular}

\section{Beban Kerja Perawat}

Berdasarkan tabel 1 tersebut menujukkan bahwa beban kerja dalam kategori berat yaitu sebanyak 91 reponden (48,7\%). Selebihnya responden dalam kategori beban kerja yang ringan sebanyak 64 responden (41,3\%). Hasil penelitian menemukan bahwa sebagian besar responden mengalami tingkat beban kerja dalam kategori berat sebanyak $48,9 \%$. Hal ini menunjukkan bahwa sebagian besar perawat di ruangan rawat inap RSUD Tugurejo semarang mengalami tingkat beban kerja yang berat. Beban kerja yang berat ini ditunjukkan dari jumlah kebutuhan perawat dilihat dari banyaknya jumlah pasien dengan macam-macam tingkat kebutuhan perawatan tidak sebanding dengan perawat yang ada diruangan sehingga tingkat beben kerja perawat dalam kategori berat.

Beban kerja perawat adalah seluruh kegiatan atau aktivitas yang dilakukan oleh seorang perawat selama bertugas di suatu unit peayanan keperawatan. Dengan demikian beban kerja yang harus ditanggung oleh perawat tergantung pada tugas perawat dalam suatu unit pelayanan keperawatan. (shoker, 2008). Penelitian ini sejalan dengan penelitian yang dilakukan oleh satria, Indahwati dan Bahry (2010) yang menemukan tingkat beban kerja yang berat terlihat pada setiap sift nya yaitu sift pagi $67,2 \%$. Sift sore $76,6 \%$ dan malam $48,4 \%$.

\section{Implementasi Patient Safety}

Berdasarkan tabel 1 di peroleh hasil dari 155 responden dengan implementasi patient safety dalam kategori baik yaitu 61 orang $(39,4 \%)$, sedangkan implementasi patient safety dalam kategori kurang baik 94 orang $(60,0 \%)$. Hasil penelitian menemukan bahwa sebagian besar implementasi patient safety dalam kategori kurang baik 94 orang $(60,0 \%)$. Implementasi patient safety kategori kurang baik ini ditunjukkan dari koesioner yang diambil dari sembilan solusi "Life Saving" ini belum sepenuhnya diterapkan dengan maksimal atau sudah dilakukan tetapi belum sesuai prosedur.

Solusi keselamatan pasien adalah sistem atau intervensi yang dibuat, mampu mencegah atau mengurangi cedera pasien yang berasal dari proses pelayanan kesehatan. Komite Keselamatan Pasien Rumah Sakit (KKPRS) mendorong rumah sakit di indonesia untuk menerapkan sembilan solusi "Life Safing" keselamatan pasien rumah sakit atau 9 solusi, langsung atau bertahap, sesuai dengan kemampuan dan kondisi rumah sakit KKPRS (2007). Implementasi atau pelaksanaan patient safety adalah bagian dari kinerja perawat, dan penilaian kinerja merupakan proses kontrol kinerja perawat yang di evaluasi berdasarkan standar tertentu. (samba, 2000) penilaian kinerja dilakukan secara efektif untuk mengarahkan perilaku karyawan dalam rangka menghasilkan jasa dengan kualitas yang tinggi. Sehingga dapat meningkatkan kualitas mutu pelayanan. Kinerja implementasi 
Tabel 2 Hubungan Beban Kerja Perawat dan Implementasi Patient Safety N= 155

\begin{tabular}{|c|c|c|c|c|}
\hline \multirow[t]{2}{*}{ Beban Kerja } & \multicolumn{2}{|c|}{ Patient Safety } & \multirow[t]{2}{*}{ Total } & \multirow{2}{*}{$X^{2} ; p$} \\
\hline & Baik & Kurang & & \\
\hline Ringan & $\begin{array}{l}33 \\
(51,6 \%)\end{array}$ & $\begin{array}{l}31 \\
(48,4 \%)\end{array}$ & $\begin{array}{l}64 \\
(100,0 \%)\end{array}$ & $\begin{array}{l}6,807 \\
\text { p:0,009 }\end{array}$ \\
\hline Berat/Tinggi & $\begin{array}{l}28 \\
(30,8 \%)\end{array}$ & $\begin{array}{l}63 \\
(69,2 \%)\end{array}$ & $\begin{array}{l}91 \\
(100,0 \%)\end{array}$ & \\
\hline
\end{tabular}

patient safety merupakan hasil kerja individu ataupun seseorang dalam melaksanakan keselamatan pasien yang telah dicanangkan oleh rumah sakit dalam membuat asuhan pasien lebih aman yang meliputi asesmen risiko, identifikasi, dan pengelolaan hal yang berhubungan dengan risiko pasien, pelaporan, dan analisis insiden, kemampuan belajar dari insiden dan tindak lanjutnya serta implementasi solusi untuk meminimalkan timbulnya risiko dan mencegah terjadinya cedera yang disebabkan oleh kesalahan akibat melaksanakan suatu tindakan atau tidak mengambil tindakan yang seharusnya diambil. Keselamatan pasien (patient safety) rumah sakit adalah suatu sistem dimana rumah sakit membuat asuhan pasien lebih aman (Permenkes, 2011).

\section{Hubungan Beban Kerja Perawat terhadap Implementasi Patient Safety}

Dari tabel 2 di kategori beban kerja pada beban kerja ringan, terlihat pada pelayanan implementasi patient safety baik $(51,6 \%)$ lebih besar dibandingkan implementasi patient safety kurang baik $(48,4 \%)$, sedangkan kategori beban kerja pada beban kerja berat, terlihat pada pelayanan implementasi patient safety kurang baik sebanyak 63 responden $(69,2 \%)$ lebih besar dari implementasi patient safety baik sebanyak 28 responden $(30,8 \%)$. Berdasarkan hasil analisis statistik dengan chi square, di dapatkan nilai $p$ value $=0,009$ dengan $d f$
$=1$ á = 0,05 (5\%) maka, apabila p value < 0,05 , Ha diterima $\mathrm{HO}$ ditolak, sehingga ada hubungan beban kerja perawat terhadap implementasi patient safety pada ruang rawat inap di RSUD Tugurejo Semarang.

Hasil penelitian menunjukkan bahwa responden atau perawat di ruangan rawat inap mengalami beban kerja dengan kategori berat yaitu, perawat di ruangan < jumlah perawat yang di butuhkan kategori implementasi patien safety kurang baik sebanyak 63 responden $(40,6 \%)$ lebih besar dari implementasi patient safety baik sebanyak 28 responden $(18,1 \%)$. Berdasarkan hasil analisis statistik dengan chi square, di dapatkan $6,807, p$ value $=0,009$ dengan $d f=1$ á $=0,05(5 \%)$ maka, apabila $p$ value $<0,05$, Ha diterima $\mathrm{HO}$ ditolak, sehingga ada hubungan beban kerja perawat terhadap implementasi patient safety pada ruang rawat inap di RSUD Tugurejo Semarang.

Hasil penelitian ini menunjukkan bahwa beban kerja perawat yang berat berpengaruh pada implementasi patient safety yang kurang baik. Beban kerja yang berbeda di Instalasi Rawat Inap RSUD Tugurejo Semarang disebabkan karena adanya perbedaan jumlah kegiatan atau aktivitas pada shift kerja, jumlah pasien, jumlah perawat serta perbedaan kelas perawatan. Adanya pelaksanaan patient safety dapat menambah tugas yang dilaksanakan oleh 
perawat sehingga perlu adanya tanggung jawab dalam menjaga pasien tetap selamat. Tugas-tugas yang bertambah yakni hand hygiene, ketepatan identifikasi pasien, peningkatan keamanan obat yang perlu diwaspadai (High-Alert), peningkatan komunikasi yang efektif, pengurangan risiko pasien jatuh dan pengurangan risiko infeksi terkait pelayanan kesehatan. karena tidak selamanya daya tahan tubuh manusia akan selalu bertahan pasti akan terjadi penurunan daya tahan tubuh. Beban kerja yang terlalu berlebihan akan menimbulkan berbagai efek yakni kelelahan baik fisik maupun mental dan reaksi-reaksi emosional seperti sakit kepala, gangguan pencernaan, kelalaian, lupa dan mudah marah sehingga secara potensial membahayakan pekerja atau perawat (Manuaba, 2000, dalam Prihatini, 2007).

Penelitian ini sejalan dengan penelitian yang dilakukan oleh sudirman (2003) yang menemukan bahwa beban kerja perawat pelaksana secara signifikan mempengaruhi kinerja perawat. Menurut Lang, et all (2004) dalam Carayon 2008, mengatakan bahwa beban kerja keperawatan berat/tinggi dapat mempengaruhi patient safety. Seperti, banyak tugas keperawatan yang perlu dilakukan oleh sekelompok perawat selama berkerja. Beban kerja keperawatan dipengaruhi juga oleh jumlah perawat, jumlah pasien, kondisi pasien dan sistem kerja perawat.

\section{KESIMPULAN}

Beban kerja perawat di ruang rawat inap RSUD tugurejo semarang sebagian besar dalam kategori berat yaitu 91 responden $(48,7 \%)$. Implementasi patient safety di ruang rawat inap RSUD Tugurejo semarang sebagian besar dalam kategori kurang baik yaitu 94 responden $(60,6 \%)$.
Berdasarkan hasil analisis statistik dengan chi square, di dapatkan nilai $p$ value $=0,009$ dengan $d f=1$ á $=0,05(5 \%)$ maka, apabila $p$ value $<0,05$, Ha diterima $\mathrm{HO}$ ditolak, sehingga ada hubungan beban kerja perawat terhadap implementasi patient safety pada ruang rawat inap di RSUD Tugurejo Semarang.

\section{REFERENSI}

Anil ,JC. (2010). Hubungan beban kerja perawat dengan stres kerja di instalasi rawat inap RSU Islam Surakarta: Universitas Muhammadiyah Surakarta

Depkes RI, (2006). Panduan nasional keselamatan pasien dirumah sakit. Departemen Kesehatan Republik Indonesia.

Dermawan, D (2013). Pengantar keperawatan profesional. Jogjakarta: Gosyen Publishing

Douglas, LM. (1992). The effective nurse: Leader and manager ., 4 Th. Ed,. Mosby - year book, Inc.

Fatimah, I (2012). Hubungan pengetahuan, motivasi dan supervisi dengan kinerja perawat dalam melaksanakan patient safety di RSUD Lambuang Baji Makasar: Universitas. Hasanudin.

Griffiths, P., Renz, A., Hughes, J., \& Rafferty, A. M. (2009). Impact of organisation and management factors on infection control in hospitals: a scoping review. Journal of Hospital Infection, 73(1), 1-14.

Hamdani, S. (2007). Analisis budaya keselamatan pasien (patient safety culture) di Rumah Sakit Islam, Jakarta 2007. Tesis. Fakultas Kesehatan Masyarakat Universitas Indonesia.

Handoko, H. (2008). Manajemen Personalia \& Sumber Daya Manusia, 
edisi kedua. BPFE-Yogyakarta: Yogyakarta.

llyas, Y. (2004). Perencanaan sumber daya manusia rumah sakit, teori, metoda, dan formula. Jakarta:

Fakultas IIImu Kesehatan Masyarakat Universitas Indonesia. Irwadi, ( 2007). http:// Irwadykapanlawi. Wordppress.Com/2007/10/28/ KKP-RS, (2006). Panduan nasional keselamatan pasien rumah sakit (patient safety). Departement Kesehatan RI.

Komite keselamatan pasien rumah sakit.( KKP-RS. (2007). Laporan insiden keselamatan pasien (IKP).

Kusnanto. (2004). Profesi dan praktek keperawatan profesional. Jakarta: ECG

Manuaba, A. Ergonomi, Kesehatan Keselamatan Kerja. Dalam Wygnyosoebroto.S Dan Wiranto.S.E."Eds, Proceeding Seminar Nasional Ergonomi PT. Guna Widya. Surabaya

Nawawi, HH. (2008). Managemen sumber daya manusia untuk bisnis yang kompetitif. Yogyakarta: Gadjah Mada University Press.

Notoatmodjo, S. (2002). Metodologi penelitian kesehatan. Jakarta: Rineka Cipta

Notoatmodjo, S. (2005). Promosi kesehatan dan ilmu perilaku kesehatan. Jakarta: Rineka Cipta

Nursalam, (2008). Konsep dan penerapan metedologi penelitian ilmu keperawatan 92nd Ed). Jakarta: Salemba Medika

Nursalam. (2008). Konsep penerapan metedologi penelitian ilmu keperawatan: Pedoman skripsi, tesis dan instrument penelitian keprawatan. Jakarta: Salemba Medika
Nursalam. (2003). Konsep dan penerapan metedologi penelitian. Jakarta : Salemba Medika.

Peraturan Menteri Kesehatan Republik Indonesia (Permenkes) Nomor 1961/ MENKES/ PER/ VIII/ 2011 Tentang Keselamatan Pasien Rumah Sakit.

Riwidikdo, H. (2007). StatistikkKesehatan. Jogjakarta: Mitra Cendekia

Samba S.(2000). Pengantar Kepemimpinan Dan Managemen keperawatan Untuk Perawat Klinis, Buku kedokteran.ECG,Jakarta.

Sudirman Muslim (2003). Hubungan Beban Kerja Dengan Kinerja Perawat Pelaksana Diruang Rawat Inap Instalasi Penyakit Dalam RSMH Palembang. Perpustakaan Universitas Indonesia.

Sukma, ND. (2012). Konsep dasar keperawatan. Jakarta: Prestasi Pustaka.

Supari, SF. (2005). Sambutan perencanaan gerakan keselamatan pasien rumah sakit. Jakarta

Suyanto. (2008). Mengenal kepemimpinan dan managemen keperawatan dirumah sakit. Jogjakarta: Mitra Cendekia.

Swansburg, R.C. \& Swansburg, R.J. (1999). Introductory management and leadership for nurses. Canada: Jones And Barlett Publishers

Wasis. (2008). Pedoman riset praktis untuk profesi perawat. Jakarta, ECG

Wijono, S. (2006). Pengaruh Kepribadian Type A dan Peran Terhadap Stres Kerja Manajer Madya. Jurnal Universitas Kristen Setya Wacana Salatiga. Insan, 8(3). 